\title{
Aortocaval Lymph Node
}

National Cancer Institute

\section{Source}

National Cancer Institute. Aortocaval Lymph Node. NCI Thesaurus. Code C118775.

A lymph node located in the area between the abdominal aorta and inferior vena cava. 